medRxiv preprint doi: https://doi.org/10.1101/2020.05.06.20093773; this version posted May 12, 2020. The copyright holder for this preprint (which was not certified by peer review) is the author/funder, who has granted medRxiv a license to display the preprint in perpetuity.

It is made available under a CC-BY-NC 4.0 International license .

\title{
Psychological Distress Among People Losing Work During the COVID-19 Pandemic in Australia
}

Authors

Alex Collie $\mathrm{PhD}^{1}$, Luke Sheehan $\mathrm{MSc}^{1}$, Caryn van Vreden $\mathrm{PhD}^{1}$, Genevieve Grant $\mathrm{PhD}^{2}$, Peter Whiteford $\mathrm{PhD}^{3}$, Dennis Petrie $\mathrm{PhD}^{4} \&$ Malcolm R Sim MBBS $\mathrm{PhD}^{1}$.

1. School of Public Health and Preventive Medicine, Monash University, Australia

2. Faculty of Law, Monash University, Australia

3. Crawford Centre for Social Policy, Australian National University, Australia

4. Centre for Health Economics, Monash University, Australia

\begin{abstract}
Introduction

This study estimated the extent of psychological distress among people losing work during the coronavirus disease of 2019 (COVID-19) pandemic in Australia, and examined associations between distress, nature of work loss and degree of social interaction.
\end{abstract}

Methods

Data were from a baseline online survey of an inception cohort recruited in the weeks following the introduction of physical distancing and movement restrictions to contain the spread of COVID-19 in Australia. These restrictions resulted in widespread unemployment and working hour reduction. Psychological distress was measured using the Kessler-6 scale. Data on nature of work loss, social interactions, demographic, job and occupational characteristics were also collected. Regression modelling was conducted to determine the relationship between work loss, social interactions and psychological distress, accounting for confounders.

$\underline{\text { Results }}$

Among the 551 study participants $31 \%$ reported severe psychological distress, $35 \%$ in those with job loss and $28 \%$ in those still employed but working less. Those who had significantly greater odds of high psychological distress were younger, female, had lost their job and had lower social interactions. The relationship between job loss and distress became nonsignificant when financial stress, and occupation were included in the regression model, but the protective effect of higher social interactions remained significant.

\section{$\underline{\text { Discussion }}$}

There was a high prevalence of psychological distress in people losing work during the coronavirus pandemic. Age, gender, job loss and social interactions were strongly associated with distress. Interventions that promote social interaction may help to reduce distress during among people losing work during the COVID-19 pandemic. 
medRxiv preprint doi: https://doi.org/10.1101/2020.05.06.20093773; this version posted May 12, 2020. The copyright holder for this preprint

\section{Introduction}

In response to the coronavirus pandemic governments internationally have sought to contain viral spread by limiting travel and physical interaction between citizens. These measures have led to large-scale unemployment. In the USA 26 million people filed applications for unemployment insurance benefits in the four weeks to $24^{\text {th }}$ April 2020 (1). In Australia an estimated 800,000 people have lost their jobs in the weeks after social distancing measures were introduced with unemployment expected to more than double (2).

The harmful impacts of unemployment on mental health are well described (3), including in people whose work is impacted by viral epidemics $(4,5)$. These effects may be mitigated by social connections (6). The protective effect of social networks may be less during the coronavirus pandemic as physical distancing presents a barrier to social interaction. Policy responses to the coronavirus pandemic thus introduce the potential for a psychological 'double whammy' of job loss combined with reductions in social interaction.

This study aimed to characterise the prevalence of psychological distress in people losing work or losing their jobs during the pandemic, and to determine the associations with social interactions. We hypothesised that job loss and lower levels of social interaction would increase the likelihood of psychological distress.

\section{Methods}

\section{$\underline{\text { Study design and procedures }}$}

We report findings from the baseline data collection of an inception cohort study of people losing work, or losing their jobs, during the COVID-19 pandemic. Participants were recruited through social and mainstream media. Inclusion criteria included age 18 years or over, working in a paid job during the final three months of 2019 , and loss of job or reduction in working hours during the COVID-19 pandemic beginning early 2020. All participants included in this paper were enrolled and completed the baseline online survey between $27^{\text {th }}$ March and 20 ${ }^{\text {th }}$ April 2020.

The study was approved by the Monash University Human Research Ethics Committee (Project ID 24003).

\section{Outcome}


medRxiv preprint doi: https://doi.org/10.1101/2020.05.06.20093773; this version posted May 12, 2020. The copyright holder for this preprint

Psychological distress was assessed using the Kessler 6 questionnaire (7). The score was calculated and categorised into low, moderate and severe psychological distress as per established criteria $(8,9)$.

\section{Exposure Variables}

Work status was dichotomised as having lost employment completely (job loss) or employed but working less.

Social interactions were measured using the Social Interaction sub-scale of the Duke Social Support Index (DSSI) (10). The scale ranges from 4 (least social interaction) to 12 (most social interaction).

\section{Other Variables}

Financial stress was assessed with the question 'If all of a sudden you had to get $\$ 2000$ for something important, could the money be obtained within a week? (11) Response options were 'yes', 'no', and 'don't know'. For analysis 'don't know' and 'no' were collapsed.

Participants selected the Australian and New Zealand Standard Classification of Occupations major group that best fitted their occupation. The categories 'Technicians and Trade Workers', 'Machinery Operators and Drivers', and 'Labourers' were combined into one group for analysis due to small sample size.

\section{$\underline{\text { Data Analysis }}$}

Frequencies and percentages were used to describe the sample given most outcomes were categorical. Mean and standard deviation was used for the social interaction as this variable is continuous. The effect of job loss and social support on psychological distress was modelled using ordinal logistic regression. Two models were estimated. The first contained only the two explanatory variables of interest: work status and social interaction along with age and gender. The second, adjusted model was based on the first but with confounder variables added. A variable was included in the model if it altered the coefficient for work status or social interaction score by more than $10 \%$ when added to the first model.

\section{Results}

551 participants were included in analysis, and had no missing data on all variables required for the regression models. The sample was over three quarters female and $61.2 \%$ were aged between 45 and 65 years (Table 1). Approximately one third (31.0\%) were experiencing 
medRxiv preprint doi: https://doi.org/10.1101/2020.05.06.20093773; this version posted May 12, 2020. The copyright holder for this preprint

severe psychological distress and a further $45.9 \%$ were experiencing moderate distress.

Almost two-thirds had lost their job. The percentage experiencing severe distress was greater in the job loss group (35.2\%) than in the still employed group (28.1\%).

\section{Baseline Model}

Both work status and social interaction had a significant effect on psychological distress in the baseline model. Each 1-point increase in the DSSI score was associated with $0.76(95 \%$ CI: 0.69-0.85) reduction in the odds of psychological distress. Participants who had lost their job had greater odds of reporting psychological distress [OR=1.47, 95\% CI: $1.05-2.06$ ]. Women and those aged under 35 years also had greater odds of distress in this model.

\section{$\underline{\text { Confounders }}$}

Financial stress and occupation confounded the interaction between outcome and exposure variables and were included in the adjusted model. A range of other variables were tested but did not alter this interaction including: being the primary earner in the household, employment type prior to changes (full-time/part-time/casual), whether an application for social assistance had been filed, self-assessed health, highest education level, job tenure, job satisfaction, days of notice before change in job status, industry, and household structure.

\section{$\underline{\text { Adjusted Model }}$}

The addition of the two confounders altered the estimated effect of the exposure variables on psychological distress. The effect on the DSSI score was minimal, with the estimated odds ratio for a 1-point increase in the DSSI score changing to 0.79 (95\% CI: $0.71,0.88)$. There was a larger attenuation on the effect of work status and this effect was no longer significant $(\mathrm{OR}=1.28,95 \% \mathrm{CI}: 0.90,1.81)$. As in the baseline model, females and younger workers had greater odds of psychological distress. Those in financial stress had elevated odds of psychological distress (OR: 1.93, 95\% CI: 1.38, 2.70). Managers were the occupation with the largest odds of experiencing psychological distress, with both professionals and sales workers having approximately only half the odds of distress.

\section{Discussion}

This study of Australians losing work or losing their jobs during the COVID-19 pandemic found that $76 \%$ of participants reported moderate or severe psychological distress. The proportion with severe psychological distress (31\%) is approximately four times that 
observed in employed Australians aged 18 to 65 years ( $~ 8 \%)$ and more than 2.5 times the rate observed in Australian adults (12). These findings extend recent Australian government data showing a higher than normal prevalence of stress, anxiety and hopelessness among the general community during the COVID-19 pandemic (2)

A greater proportion of people experiencing job loss reported severe psychological distress than those still employed. This difference was statically significant in a baseline model adjusting for age, gender and social interaction, but non-significant when other confounders were included in an adjusted model. This finding suggests that the pathway from job loss to psychological distress may be mediated by financial stress and occupation. In contrast the effect of social interactions remained robust and statistically significant in both baseline and adjusted models. People reporting greater social interaction were less likely to report psychological distress. Maintaining or enhancing social interactions may be a strategy that can support positive psychological outcomes in people experiencing employment shocks during the COVID-19 pandemic.

Study limitations include its cross-sectional nature and reliance on self-report. The sample may not be representative of the population affected. Strengths include the use of validated measurement instruments, the temporal proximity of data collection to job and work loss and that the analysis accounted for multiple confounders.

To our knowledge, this is one of the first studies examining psychological distress specifically among people losing work during the COVID-19 pandemic. Many nations are experiencing substantial economic downturns and sharp rises in unemployment. Further studies of psychological complaints amongst people whose work has been adversely impacted during the COVID-19 pandemic, and strategies to mitigate any negative impacts, are warranted. 
medRxiv preprint doi: https://doi.org/10.1101/2020.05.06.20093773; this version posted May 12, 2020. The copyright holder for this preprint (which was not certified by peer review) is the author/funder, who has granted medRxiv a license to display the preprint in perpetuity.

It is made available under a CC-BY-NC 4.0 International license .

\section{References}

1. US Department of Labor. Unemployment Insurance Weekly Claims Report - Week Ending 25 April 2020. Washington, D.C: US Department of Labor; 2020.

2. Australian Bureau of Statistics. Household Impacts of COVID-19 Survey, 14-17 April 2020, Australia Canberra; 202005 May 2020. Contract No.: 49400DO004_2020.

3. Crowe L, Butterworth P. The role of financial hardship, mastery and social support in the association between employment status and depression: results from an Australian longitudinal cohort study. BMJ Open. 2016;6(5):e009834.

4. Zhang SX, Wang Y, Rauch A, F. W. Health, distress, and life satisfaction of people one-month into COVID-19 outbreak in China. medRxiv [Internet]. 202024 March 2020.

5. Taylor MR, Agho KE, Stevens GJ, Raphael B. Factors influencing psychological distress during a disease epidemic: data from Australia's first outbreak of equine influenza. BMC Public Health. 2008;8:347.

6. Menec VH, Newall NE, Mackenzie CS, Shooshtari S, Nowicki S. Examining social isolation and loneliness in combination in relation to social support and psychological distress using Canadian Longitudinal Study of Aging (CLSA) data. PLoS One. 2020;15(3):e0230673. 7. Kessler RC, Andrews G, Colpe LJ, Hiripi E, Mroczek DK, Normand SL, et al. Short screening scales to monitor population prevalences and trends in non-specific psychological distress. Psychological medicine. 2002;32(6):959-76.

8. Kessler RC, Barker PR, Colpe LJ, Epstein JF, Gfroerer JC, Hiripi E, et al. Screening for serious mental illness in the general population. Archives of general psychiatry. 2003;60(2):184-9.

9. Prochaska JJ, Sung HY, Max W, Shi Y, Ong M. Validity study of the K6 scale as a measure of moderate mental distress based on mental health treatment need and utilization. International journal of methods in psychiatric research. 2012;21(2):88-97.

10. Koenig HG, Westlund RE, George LK, Hughes DC, Blazer DG, Hybels C. Abbreviating the Duke Social Support Index for use in chronically ill elderly individuals. Psychosomatics. 1993;34(1):61-9.

11. Australian Bureau of Statistics. General Social Survey (GSS): Household Survey Questionnaire. Canberra: Australian Bureau of Statistics; 2014.

12. Australian Bureau of Statistics. National Health Survey 2014-15. In: Australian

Bureau of Statistics, editor. Canberra: Australian Bureau of Statistics; 2015. 
Table 1. Results of the ordinal logistic regression models with psychological distress as the outcome.

\begin{tabular}{|c|c|c|c|c|c|c|c|c|c|}
\hline \multirow{3}{*}{$\begin{array}{l}\text { Variable } \\
\text { Gender }\end{array}$} & \multirow[b]{2}{*}{$\begin{array}{l}\text { Number }(\%) \\
\text { unless stated }\end{array}$} & \multicolumn{4}{|c|}{ Baseline model } & \multicolumn{4}{|c|}{ Adjusted model } \\
\hline & & $\begin{array}{l}\text { Odds } \\
\text { Ratio }\end{array}$ & \multicolumn{2}{|c|}{$95 \% \mathrm{CI}$} & \multirow[t]{2}{*}{ p Value } & $\begin{array}{l}\text { Odds } \\
\text { Ratio }\end{array}$ & \multicolumn{2}{|c|}{ 95\% CI } & \multirow[t]{2}{*}{ p Value } \\
\hline & & & & & & & & & \\
\hline Woman & $431(78.2 \%)$ & $1($ Ref $)$ & & & & $1(\operatorname{Ref})$ & & & \\
\hline Man & $120(21.8 \%)$ & 0.62 & 0.42 & 0.92 & 0.02 & 0.59 & 0.39 & 0.90 & 0.01 \\
\hline \multicolumn{10}{|l|}{ Age } \\
\hline 18 to 24 years & $30(5.4 \%)$ & 3.94 & 1.83 & 8.50 & $<0.001$ & 4.48 & 2.01 & 9.97 & $<0.001$ \\
\hline 25 to 34 years & $72(13.1 \%)$ & 2.40 & 1.42 & 4.07 & 0.001 & 2.48 & 1.45 & 4.24 & 0.001 \\
\hline 35 to 44 years & $101(18.3 \%)$ & 1.36 & 0.85 & 2.16 & 0.20 & 1.27 & 0.79 & 2.05 & 0.32 \\
\hline 45 to 54 years & $180(32.7 \%)$ & $1(\operatorname{Ref})$ & & & & 1 (Ref) & & & \\
\hline 55 to 65 years & $157(28.5 \%)$ & 0.73 & 0.48 & 1.09 & 0.13 & 0.73 & 0.48 & 1.10 & 0.13 \\
\hline Over 65 years & $11(2.0 \%)$ & 0.44 & 0.13 & 1.53 & 0.20 & 0.40 & 0.12 & 1.42 & 0.16 \\
\hline \multicolumn{10}{|l|}{ Work Status } \\
\hline Unemployed / lost job & $355(64.4 \%)$ & $1(\operatorname{Ref})$ & & & & $1(\operatorname{Ref})$ & & & \\
\hline Employed but not working or working less & $196(35.6 \%)$ & 1.47 & 1.05 & 2.06 & 0.03 & 1.28 & 0.90 & 1.81 & 0.17 \\
\hline $\begin{array}{l}\text { Mean (SD) Duke Social Interaction sub- } \\
\text { scale }\end{array}$ & $6.76(1.58)$ & 0.76 & 0.69 & 0.85 & $<0.001$ & 0.79 & 0.71 & 0.88 & $<0.001$ \\
\hline \multicolumn{10}{|l|}{$\begin{array}{l}\text { Could } \$ 2000 \text { be raised in a week for an } \\
\text { emergency? }\end{array}$} \\
\hline Yes & $281(51.0 \%)$ & & & & & 1 (Ref) & & & \\
\hline No / Not Sure & $270(49.0 \%)$ & & & & & 1.93 & 1.38 & 2.70 & $<0.001$ \\
\hline \multicolumn{10}{|l|}{ Occupation } \\
\hline Managers & $75(13.6 \%)$ & & & & & $1(\operatorname{Ref})$ & & & \\
\hline Professionals & $121(22.0 \%)$ & & & & & 0.56 & 0.32 & 0.99 & 0.05 \\
\hline Community and Personal Service & $63(11.4 \%)$ & & & & & 0.59 & 0.31 & 1.14 & 0.12 \\
\hline
\end{tabular}




\begin{tabular}{|c|c|c|c|c|c|}
\hline \multicolumn{6}{|l|}{ Workers } \\
\hline Clerical and Administrative & $81(14.7 \%)$ & & & & \\
\hline Workers & & 0.71 & 0.38 & 1.33 & 0.28 \\
\hline Sales Workers & $61(11.1 \%)$ & 0.48 & 0.24 & 0.93 & 0.03 \\
\hline $\begin{array}{l}\text { Technician and Trade Workers, } \\
\text { Machinery Operators and Drivers, }\end{array}$ & $73(13.2 \%)$ & & & & \\
\hline and Labourers & & 0.71 & 0.38 & 1.32 & 0.28 \\
\hline Don't know / Not specified & $77(14.0 \%)$ & 0.63 & 0.33 & 1.18 & 0.15 \\
\hline
\end{tabular}

Note: The baseline model includes age, gender, work status and social interaction. The adjusted model includes those variables and an indicator of financial stress and occupation. $\mathrm{CI}=$ Confidence Interval. Ref $=$ Reference category 
medRxiv preprint doi: https://doi.org/10.1101/2020.05.06.20093773; this version posted May 12, 2020. The copyright holder for this preprint (which was not certified by peer review) is the author/funder, who has granted medRxiv a license to display the preprint in perpetuity.

$$
\text { It is made available under a CC-BY-NC } 4.0 \text { International license. }
$$

